August 2011

\title{
George Steiner and the War against the Jews: A Study in Misrepresentation
}

Roger W. Smith

Follow this and additional works at: https://digitalcommons.usf.edu/gsp

\section{Recommended Citation}

Smith, Roger W. (2011) "George Steiner and the War against the Jews: A Study in Misrepresentation," Genocide Studies and Prevention: An International Journal: Vol. 6: Iss. 2: Article 8.

Available at: https://digitalcommons.usf.edu/gsp/vol6/iss2/8

This Articles is brought to you for free and open access by the Open Access Journals at Digital Commons @ University of South Florida. It has been accepted for inclusion in Genocide Studies and Prevention: An International Journal by an authorized editor of Digital Commons @ University of South Florida. For more information, please contact digitalcommons@usf.edu. 


\title{
George Steiner and the War against the Jews: A Study in Misrepresentation
}

\author{
Roger W. Smith \\ College of William and Mary
}

\begin{abstract}
The literary and cultural critic George Steiner has been described as the preeminent literary critic of the past fifty years. Certainly, he has written eloquently about aspects of the Holocaust, and his emphasis on language and its power to make and unmake much of human life, has been widely influential. Yet Steiner's work on the Holocaust is misleading in its interpretations, explanations, and implications. Part of this stems from his worry that the Jews brought their near destruction upon themselves: that they had invented the practice of genocide, had invented the idea of a "chosen people," had through Moses, Jesus, and Marx created such moral demands upon ordinary human beings that the tension became unbearable and resulted in a revolt against the tyranny of conscience and perfection. Part of it comes from his uncritical focus on Freudian psychology and reliance on literary works as a substitute for history. Yet there is almost always the dazzling prose, which can overwhelm critical thought and lead one away from a factual understanding of the origins and consequences of the Holocaust. The present article provides a critical assessment of Steiner's interpretation of the Holocaust, its antecedents, causes, and consequences.
\end{abstract}

Key words: Holocaust, forms of explanation, George Steiner, Moses, Freud, survivors

Genocide is a species of total war, but one in which the attempt is not to defeat the "enemy" using any means possible, but rather to eliminate the "enemy" in whole or in part, whether armed or unarmed. This was the pattern in the ancient world and it is now common in the modern age, with Rwanda being the most recent case. The example best known today is what some historians call "The War against the Jews," while most others know it as the Holocaust. ${ }^{1}$

The literary and cultural critic George Steiner has written eloquently about aspects of the Holocaust in numerous essays and books. Many of us who came of age in the 1970s in the United States and write about genocide were influenced by his focus on the power of the "Word": language and its power to make and unmake much of human life. Here is the concern he has about language but also about the power of the humanities to curb violence against humans:

Central to everything I am and believe and have written is my astonishment, naïve as it seems to people, that you can use human speech both to bless, to love, to build, to forgive and also to torture, to hate, to destroy, and to annihilate. ${ }^{2}$

Nathan Scott of the University of Virginia described George Steiner as the preeminent literary critic of the last half of the twentieth century, and the late Terrence Des Pres, a Holocaust scholar of the first order, said there was "no doubt of his brilliance."3

Roger W. Smith, "George Steiner and the War against the Jews: A Study in Misrepresentation." Genocide Studies and Prevention 6, 2 (August 2011): 193-202. (C) 2011 Genocide Studies and Prevention. doi:10.3138/gsp.6.2.193 
Yet Steiner's work on the Holocaust is misleading in its interpretations, explanations, and implications. Part of this stems from Steiner's own worry that the Jews brought their near destruction upon themselves: that they had invented the practice of genocide, had invented the idea of a "chosen people," had through Moses, Jesus, and Marx created such moral demands upon ordinary human beings that the tension became unbearable and resulted in a revolt against the tyranny of conscience and perfection. Part of it stems from his uncritical focus on Freudian psychology, reliance on literary works as a substitute for history, and apparent distance from empirical social science. One appreciates Steiner's deep moral concern, his Enlightenment belief in the power of the humanities to shield us from barbarism, and his vivid and often dazzling prose. In these and other ways, Steiner is, in Plato's phrase, "the Honeyed Muse," the artist whose work is seductively beautiful, but leads us radically astray.

Steiner imagines in all sincerity that it was the ennui of bourgeois culture at the close of the nineteenth century that helped pave the way for visions of destruction, culminating in the attempt to destroy the Jews; that the density of population in the industrial-urban milieu triggered instincts of devastation or, as he puts it, "some obscure but primal need for free space, for the silence in which the ego can cry out its mastery" 4 ; that the concentration camps that played a decisive role in the killing of Jews (and others) were a literal version of "Hell," forgetting that in Christian belief Hell was a place of justice. And he subscribes to Elias Canetti's view that the Holocaust was made possible by the abstraction of large numbers related to the collapse of currency in the 1920s. Large numbers had only "unreal meaning" which "tainted with unreality the disappearance and liquidation of peoples." 5 On the other hand, Steiner is particularly concerned with why literature and other aspects of the humanities did not prevent the Holocaust and indeed originated in a land of high civilization. As often is the case with Steiner, there are important points scored but opportunities missed. Here he gives no consideration to civic and political culture, which may well serve as barriers to genocide or spurs to it. And one final example: he alters the concept of "survivor" beyond recognition.

\section{The Survivor Theme}

One can relate to Steiner's deep concern with the failure of the humanities to serve as a barrier to the Holocaust yet point out his lack of understanding of the importance of civic and political awareness, the role of authoritarian culture (he can deal with this only in terms of the German language), and how, in a time of crisis, the humanities and their claims to furthering a disposition toward decency and morality can be overcome by nationalism and the psychology of "us and them."

On the other hand, what is one to make of Steiner's claim that he is "a kind of survivor?"6 Not a "literal survivor," but "a kind of survivor." His family left France in 1940, shortly before the Nazis arrived, and lived a comfortable life in New York City as the Holocaust proceeded. Some critics have described Steiner's claim as arrogant, self-indulgent, and masochistic (the latter comes from non-psychologists who have read a little Freud). Those statements may well be right, but my own reflections are quite different.

Steiner was born in Paris on 23 April 1929; he attended a Lycee there until the family moved to New York in January 1940. With the exception of Steiner and one other student, all of the Jewish students in his school were killed by the Nazis with the collaboration of the French police. Today, all over Paris, there are schools that 
have inscriptions that mention the destruction of their Jewish students and speak of the collaboration of the French authorities in carrying it out.

George Steiner writes,

We left France, where I was born and brought up in safety. So I happened not to be there when the names were called out. I did not stand in public squares with the other children with whom I had grown up. Or see my father or mother disappear with the train doors torn open. But in another sense I am a survivor, and not intact. ${ }^{7}$

He sees himself as a survivor, not only because of his fellow students who did not survive, but because the "black mystery of what happened in Europe is to me indivisible from my own identity." 8 He cannot be normal; his relationships with others are simply different because of the Holocaust, or at least that is what he says. And he appears to have a deep desire to enter into the pain of those who died, who were killed in a horrible manner. Nowhere does he express it more openly than in his commentary on a poem by Sylvia Plath.

Shortly before the American poet Sylvia Plath committed suicide by putting her head into a gas oven, she wrote a number of Holocaust poems. Steiner thought some of them went to the heart of what the Holocaust experience must have been and noted that they came from an American, non-Jewish woman. But I think he also had himself in mind when he wrote the following: "Perhaps it is only those who had no part in the events who can focus on them rationally and imaginatively; to those who experienced the thing, it has lost the hard edges of possibility; it has stepped outside the real." 9

So according to Steiner, those who were not there, in the places of deportation and killing, are those who can report accurately on what happened in the ghettos and in the camps and are the ones who, unlike the victims, can make sense of the terrible events. Steiner characteristically does not make many comparative statements. Was this true only of the Holocaust, or would he extend the same vision to the Armenians, Cambodians, Tutsi? This kind of approach is one of the reasons that critics have argued that Steiner is using the Holocaust to aggrandize himself, claiming to be a kind of survivor. But if it is a matter of being "affected" (a loose and indefinite word) by genocide - any genocide-who, except those who are indifferent, is not a survivor; who is not a victim? Genocide is a crime committed on the body of a particular people, but also against humankind. It reduces for all time biological and cultural possibilities, it reduces the plurality of human existence, and, when any group claims the right to determine who has the right to live, all humans are under attack. Still, is not the basic notion of a "survivor" that of one who has been directly victimized and has somehow survived and gone on, more or less, with a life? Steiner, with whose personal account I am sympathetic, alters the whole concept of what a "survivor" is, distorting it beyond recognition, diluting and diverting it, as we shall see, into a matter of identification and the preservation of a Jewish humanistic tradition.

What about those ethnic/racial/religious groups whose recent ancestors (and the question can be raised, how far back do we go?) have been subjected to genocide? Some will have strong cultural or intellectual traditions, while others may not. If we adopt Steiner's standard, they would seem to be of lesser importance, less likely to be "survivors" than he is. But then his standard is very individualistic, very much a matter of egocentrism, and he certainly privileges the Holocaust over all other genocides, and in that he is not alone. Yet how many Jews, from whatever country or circumstances during or after the Holocaust, qualify in his terms as a "kind of 
survivor?" Is this a solo act? Has he ever sought out those who were free from the direct terror of the Nazi onslaught, living in a safe environment during the Holocaust, but who have his sense of being "a kind of survivor?" It could be an extraordinary exercise, painful, dissonant, even confirmatory.

The problem that I have with Steiner's use of the idea of the "survivor" is that it distorts the concept of "survivor," it shows disrespect for actual survivors of the Holocaust, and it privileges a literary and humanistic life, equating writing a few books with the millions who died in the Holocaust. The other problem I have with his approach is that he never discusses the other genocides (Armenian, Cambodian, Rwandan, and others) in the same terms. Of course, he is providing a kind of memoir of his own obsession with the Holocaust ("the Holocaust left its mark on me"), but a few comparative statements would have been helpful. Do those who were potential victims of other recent genocides, but were safe because abroad, see themselves as survivors? Or is Steiner reflecting on his own experience and aspiration rather than pointing to a common reaction of those saved from victimization by geographical separation?

The themes that Steiner addresses in Plath's poems can be described as masochistic, but I would see his concern with them as a matter of empathy. On the other hand, he gives credence to other interpretations. In speaking of Plath's poem "Daddy," in which she "became a woman being transported to Auschwitz,"10 he deeply identifies with her evocation of events that she had not actually witnessed, but with which she had a fateful identification and longing. Speaking for her, but also for himself, Steiner writes, "Was there latent in Sylvia Plath's sensibility, as in that of many of us who remember only by fiat of imagination, a fearful envy, a dim resentment at not having been there, of having missed a rendezvous with hell?"11

Steiner is a survivor of sorts, but only at a distance; he can only imagine what his schoolmates and Jews of many backgrounds suffered. He wishes that he had been there and claims that he was envious for having "missed a rendezvous with hell." Yet he sees himself as a "kind of survivor." His relations with others, his life's work, and his daily thought revolve around the Holocaust. Still what is striking about Steiner's claim to be a kind of survivor is his cultural claim that he is one of the last survivors of the lost and destroyed Jewish humanistic culture of the nineteenth and early twentieth centuries: Heine, Bergson, Hofmannstahl, Proust, Marx, Kafka, Freud; Wittgenstein should certainly be added to the list. But Steiner is attuned to the Word and leaves out the strong presence of the many composers of Jewish origin, such as Mahler and Stravinsky, and of major artists, such as Chagall, perhaps because he can only see himself as a successor to literary artists and critics, not philosophers, painters, and musicians. ${ }^{12}$ But that leaves out an amazing part of the Jewish humanistic contributions to contemporary life and defies his notion that most of the Jewish contributions are now behind us, partly because of the Holocaust, but for other reasons as well.

That which has been destroyed-the large mass of life so mocked, so hounded to oblivion that even the names are gone and the prayer for the dead can have no exact foothold-embodied a particular genius, a quality of intelligence and feeling which none of the major Jewish communities now surviving preserved or recaptured. Because I feel that specific inheritance in my own reflexes in the work I try to do, I am a kind of survivor. ${ }^{13}$

Steiner goes on to talk about the humanities in Central Europe and how Jewish contributions were at the forefront, not only among intellectuals but in communities 
as well, whether in Prague, Vienna, Berlin, or Paris. But he comments, after the Holocaust, "Almost nothing of it survives." 14 Still, he sees himself as a successor to the great figures who had gone before, a successor to the Jewish humanistic culture that has now largely disappeared. He wants to think of himself in this respect as one who keeps a tradition alive and, in his view, thus as a survivor. ${ }^{15}$

Steiner is good with words, but here he fails: rather than "survivor," the appropriate term is "heir." He may well be the heir to a tradition, a heritage, which he sees as his duty to continue, but this is a far cry from the idea of a survivor. Yes, cultures survive or they don't, but it is a fallacy to confuse the survival of a culture with the survival of humans in the face of politically imposed death. Steiner surely must be aware that being a survivor in a literary sense-which as I have suggested is a misuse of words - cannot be equated with the same notion of survival where victims of the Holocaust, or of any genocide, are concerned.

\section{The Central Argument}

I have already referred to some of Steiner's explanations of the Holocaust: density of population, noise that sets one's nerves on edge, large numbers losing their meaning due to inflation, and thus an intellectual inability to respond to the mass killings of so many millions of people in Europe. These are contained in Steiner's most powerful statement of his understanding of why the Holocaust took place and why the Jews were its victims, his eloquent and seductive essay "A Season in Hell" in In Bluebeard's Castle, published in 1971. These claims can be easily dismissed. If it were a question of density, lack of personal space, and noise, then genocides should have broken out-in fact should be taking place at this very moment-in Tokyo, Mexico City, Sao Paulo, New York, Marseille. And with regard to the large-numbers thesis, there are two issues: first, how many people actually knew the extent of the killing of Jews? In Germany, not so many; in Ukraine, where executions were in the open, more people were aware of it. And, second, why does Steiner not mention the other groups, such as Gypsies and Soviet prisoners of war, who were killed by the Nazis in incredible numbers? I shall come to this in a moment, but other mass killings do not fit into Steiner's theological explanation of the Holocaust. His narrative and explanation only refer to Jews. Even within the killing done by the Nazis and their allies, there were others killed and, of course, those killed in genocides before and after the Nazi period.

There is an additional issue here: even if Germans knew about many of the deaths (which is questionable) but large numbers had blunted their capacity to respond, might they not have understood that war-especially modern, total warclaims many victims, civilian and military, but could still have wondered why all the other killings took place? Put differently, if big numbers explain some things, they do not explain much. But if one wants to pursue the theme, the inability to respond to the massive loss of life during World War II, from whatever causes, was most likely due to the mass carnage of World War I, where in the Battle of the Somme alone over a million and a half casualties occurred and an additional 700,000 at Verdun.

Steiner has misrepresented the Holocaust and the antecedents of genocide, here and in other cases. But the heart of his argument is that the cause of the Holocaust was Moses, Jesus, and Marx-Jewish perfectionism and ethical pressure on an unwilling human nature. He reaches the conclusion that the Jews brought the Holocaust upon themselves. ${ }^{16}$ He even writes a novel in which Hitler is alive, though old, in the Amazon rain forest, and Hitler says that everything he did he learned 
from the Jews. ${ }^{17}$ Although this is a novel, there is a close similarity between Hitler's arguments in a trial held in the jungle and Steiner's own arguments and, indeed, closeness of language. Shakespeare is not Hamlet, and Steiner is not the A.H. of his fiction, but Steiner identifies a type of closeness, not necessarily between himself and Hitler (God forbid), but between ancient Judaism and Hitler's ideology. He mentions that the 90-year old Hitler has a "withered right arm." And so does George Steiner due to a birth defect. How do we interpret this? Is it just a coincidence or something more? Is it perhaps a recognition, in terms of the Hitler speech, that Judaism and Nazism have some things in common: the idea of a "chosen people" and the idea that ancient Hebrews committed genocide repeatedly, and perhaps even invented the practice? This is the great burden that hangs over Steiner, and it is an extraordinary question: Did the Jews create the very model of their destruction? Is Hitler correct in identifying the Jews as his inspiration for the destruction of that group?

Steiner is right to recognize that the ancient Jews did engage in what today would be called genocide. If we can trust the accounts in the early books of the Bible, such as that in Numbers 31, again and again, whole groups were destroyed. ${ }^{18}$ But what Steiner and his fictional Hitler (or A.H. as he is called in The Portage to San Cristobal of A.H.) fail to tell us is that the attempt to eliminate whole groups was the common mode of warfare in early society. The Assyrians in the eighth century BCE, for example, embarked on genocidal destruction almost annually, afterward erecting monuments boasting of their "success." Beyond that, the Greeks and Romans also engaged in the destruction of whole groups (Melos and Carthage, for example). And Hitler would have been aware of the destruction wreaked by Genghis Khan, but above all, the Young Turk genocide of over one million Armenians that began in 1915 .

Two facts stand out: no one knows who invented genocide, and those who have sought to commit it have had no lack of models from which to choose. Nevertheless, Steiner is caught in a web of anxiety over the possibility that not only had the Jews brought on their own destruction, but that they provided the basic idea of how to carry out the elimination of a people.

With regard to the exclusiveness and exalted status of a particular group, a "chosen people," Steiner hardly puts up a fight. The "poison," he says, "is in ancient part, Jewish." 19 But is there no difference between a people chosen by God to bring his presence into the world and who have deep responsibilities imposed upon them by God and, on the other hand, a "master race" that is biological, naturalistic, with no assigned moral imperatives? Steiner could have pursued these issues, but he does not; this again suggests his acceptance of the Jews' responsibility for the Holocaust.

He describes the matter as follows:

By one of the cruel, deep ironies of history, the concept of a chosen people, of a nation
exalted above others by a particular destiny, was born in Israel. In the vocabulary of
Nazism there were elements of a vengeful parody on the Judaic claim. The theological
motif of a people elected at Sinai is echoed in the pretense of the master race and its
chiliastic dominion. Thus there was in the obsessed relation of Nazi to Jew a minute
but fearful grain of logic. ${ }^{20}$

But Steiner should surely tell us of what the "elements of parody" consist, and since there is only a "minute" element of logic connecting the ancient Jewish claim with that of the Nazis' master race, what is that minute element and how are the two concepts otherwise distinguished? Still, these issues provide more evidence of the cloud that hangs over him and lead to serious misrepresentations of the Holocaust and, above all, the question of why. 
Steiner's central argument is a variant on Freud's in Civilization and Its Discontents. ${ }^{21}$ Freud claimed that society was increasingly imposing moral demands on individuals that were contrary to their nature and which they could not possibly fulfill. The attempt was to curb sexuality (he was writing in 1929) and human instincts toward aggression. But the demands, which he termed the "cultural superego," collided with the instinctual needs (the id) of individuals. The result was enormous tension between the ethical exhortations/demands and the biologically based needs of the individual. Freud saw an increasing sense of guilt, unhappiness, and neurosis in society and argued for a lowering of the moral burdens on individuals. Freud's individuals were rebels, but impotent rebels; they were unhappy, a few of them committed crimes to relieve the pressure, but many others either accepted their unhappiness or became anxious, depressed, or neurotic; and many women, unlike men, became hysterical.

Steiner's individuals (but why only in Germany and a few other places?) are also rebels who can no longer bear the demands made upon them, but instead of retreating into neurosis, they become killers. But such an explanation will not do. Not everyone in Germany or anywhere else engaged in genocide. So, how does one distinguish between those who felt the pressure of righteous, yet utopian, demands and did not kill and those who felt the same demands and did kill?

To go back to the beginning, Steiner argues that the Jews/Moses invented monotheism. In effect, they invented God, but an invisible God, one who was all demanding and was the only God, displacing the polytheism that was for people at the time the fundamental means by which to explain the world in which they lived. Then Jesus followed, with his radical demands for ascetic love, compassion, self-suppression, and the disdain of worldly goods. Finally, there was Marx and the claims of a socialist society, in which privilege and property would be abolished and all forms of oppression would be eliminated. ${ }^{22}$

Three times a demand was made for perfection and self-sacrifice; three times, that is, a utopian demand was made that collided with ordinary human capacities to respond. Three times, a Jew was at the center: Moses, Jesus, Marx. But Steiner tells us,

Nothing is more cruel than the blackmail of perfection. We come to hate, to fear most those who demand of us a self-transcendence, a surpassing of our natural and common limits of being. Our hate and fear are the more intense precisely because we know the absolute rightness, the ultimate desirability of the demand. In failing to respond adequately, we fail ourselves. And it is of deep-lying self-hatreds that hatreds spring. ${ }^{23}$

Here, one may object to Steiner's assumption about the "absolute rightness" that "we" accept. Who is the "we?" And is it not the case that many persons are atheists and so the question of one God as opposed to many is not an issue? Also, there are few individuals who have ever been able to respond to the radical demands of Jesus, though lip service has undoubtedly been paid to them. And while Marx has had many adherents, and still does in an intellectual sense, how many people can believe in the possibility of a utopian society as Marx had presented it?

But if "we" do not accept monotheism or God, if "we" do not respond to the radical demands of Jesus, and if "we" either reject the demands of Marx or do not see the possibility of actually bringing about the kind of society he had in mind, then where will the anger come from or the hate that will be directed toward Jews? And why only Jews? Why not Christians and many others as the object of hatred? 
Well, as it turns out, the Nazis had a very long list of those to be killed and it was not limited to what Steiner imagines as the Jews appearing three times, demanding perfection and self-sacrifice.

The details are different, but the theory is Freud's: cultural demands and a sense of guilt collide with the instinctual portion of human nature, the id. Something has to give: for Freud the moral demands lead to neurosis; for Steiner they lead to the Holocaust.

It is a convenient and simple theory, but it ignores almost all of the facts leading up to the Holocaust: social, political, ideological (social Darwinism and racial science, preceded by a long history of anti-Semitism). And it does not account for the fact that the Holocaust did not take place earlier. Just when did the revolt against the three Jewish utopians build up, and why at that moment? Why not elsewhere as well? Also, why was the Holocaust mainly directed against Jews? Since Steiner indicates that Jesus was a central figure here, why not against Christians as well? And how can any of what Steiner proposes about the origin of the Holocaust, explain, or help to explain, any other genocide?

In the end, Steiner takes the Nazi onslaught against the Jews as retribution for Moses, Jesus, and Marx.

\section{Concluding Remarks}

George Steiner, now in his eighties, is the author of some twenty books and hundreds of articles and reviews, with many awards for his cultural and literary contributions. He was educated at the University of Paris, the University of Chicago, Harvard, and Oxford, and was a fellow at the Institute for Advanced Study at Princeton. He has been in residence or lectured at most of the major universities in the Western world, including Oxford, Cambridge, Harvard, and Stanford, among many others. He was for many years Professor of Comparative Literature at the University of Geneva, where he gave lectures in four languages.

Steiner is a brilliant writer who has spent years interpreting the destruction of the Jews. His narrative has never changed, yet the ideas can startle: the Jews were killed, not because they "Killed God," but because they "invented God." 24 An interesting idea to be sure, but totally unanchored in historical fact.

Various scholars have said that Steiner's views on the Holocaust were the result of a split in his personality, that he was self-hating, that he was simply arrogant. I cannot speak to any of these comments, but my own are very different.

I have argued, and I think shown, that George Steiner, even though obsessed with the Holocaust, has seriously misrepresented it in various ways. He is not a person who relates to social science studies; he has a superficial acquaintance with Freud but bases much of his argument on one of Freud's popular works; and he is not someone who thinks historically, despite his claim to do so. He is decidedly ahistorical and that is where many of the problems with his work begin and end.

The basic problem with Steiner's work is that, despite his apparent use of history, his whole approach is literary. For him symbols are everything, and they involve both representation and causation. He identifies a text, Dante's Inferno, and then sees it as the model for concentration camps; he sees some similarity between this and that, and explains it in terms of cultural determinism. But cannot there be similarity without direct causation? Or does cultural determinism put symbols to work with almost foreordained results? Steiner starts with a symbol and then points to a result, but fails to fill in the historical, empirical connection between the two; or he starts with a result, and then hunts for a symbol that can be said to have served 
as a model or inspiration for the event, but again, he does not make the actual connection. Is social and historical reality only a matter of symbols and metaphors and is that the theory of knowledge that Steiner has adopted? In effect, Steiner's approach is long on assumption and short on demonstration. This is perhaps not surprising since he is known to have said that the Holocaust cannot be explained by empirical and historical analyses since these are unable to reach down to "the roots of the inhuman." 25

But does his reliance on Freud and the revolt against instinctual repression get down to the roots of the inhuman? Far from it, and it is worth noting that Freud thought that socialism could relieve pressures on individuals in their quest to live a full life. Also, while he dismissed all religion as an illusion, Freud never considered heightened moral pressures as a problem that derived from monotheism. Nor did he put Moses at the center; Moses is not even mentioned in Civilization and Its Discontents. Moreover, Freud even suggested in Moses and Monotheism (1939) that Moses was not a Jew at all, but rather an Egyptian who was murdered by the Jews as they approached the Promised Land. It is Steiner's idea of an instinctual revolt against the Jewish demand for perfection by Moses, Jesus, and Marx, which after a genesis of 3000 years came to a fever pitch in the twentieth century, that remains to be documented if, indeed, it can be.

Steiner never demonstrates that there was such instinctual repression or, if there were, that it was identified as emanating from Jews. And even if it were, why did the Holocaust occur when it did (not earlier or later) and where it did? Were people in other lands having a jolly time, while only the Germans were instinctually repressed to the breaking point?

\section{Notes}

1. The present article is based upon a paper presented at the International Conference on "Varieties of Experience II" (University of Caen, France, 27-29 May 2010).

2. D. J. R. Bruckner, “Talk with George Steiner," New York Times Book Review, 2 May 1982, 20.

3. Nathan A. Scott Jr., "Steiner on Interpretation," in Reading George Steiner, ed. Nathan A. Scott Jr. and Ronald A. Sharp (Baltimore: Johns Hopkins University Press, 1994), 113, 1; Terrence Des Pres, "Kulturkritiker," Nation 240 (2 March 1985): 241.

4. George Steiner, In Bluebeard's Castle: Some Notes Toward the Redefinition of Culture (New Haven, CT: Yale University Press, 1971), 51.

5. Ibid., 53. The overview of Steiner's arguments is based on this text.

6. George Steiner, "A Kind of Survivor" [1965], in Language and Silence: Essays on Language, Literature, and the Inhuman (New York: Atheneum, 1967), 140-54.

7. Ibid., 140 .

8. Ibid.

9. George Steiner, "Dying Is an Art," in Language and Silence, 295-302, 301.

10. Ibid.

11. Ibid.

12. On the other hand, Steiner says that late in life he is consumed with music, not only the Word: music is the "center of me." See George Steiner, "A Responsion," in Scott and Sharp, Reading George Steiner, 275-86, 283-84. His notion of music is, however, not that of Bach, Mozart, or Verdi: "the question 'what in the world is music like?' has become for me the 'metaphysical inquiry incarnate." Steiner, "Dying Is an Art," 301.

With few exceptions, Steiner has not written about music, but where he did, it was with distinction. See George Steiner, "Schoenberg's Moses and Aaron," in Language and Silence, 127-39. I have never seen anything from Steiner about painting, but that has surely involved the humanistic tradition also. 
13. "A Kind of Survivor," 145.

14. Ibid., 147.

15. Ibid., 145.

16. George Steiner, "A Season in Hell," chap. 2 in In Bluebeard's Castle, 27-56; George Steiner, The Portage to San Cristobal of A.H. (New York: Simon and Schuster, 1981), chap. 17.

17. The Portage to San Cristobal of A.H., 163

18. Steiner mentions Joshua, but Numbers 31 is more instructive. See Roger W. Smith, "Women and Genocide: Notes on an Unwritten History," Holocaust and Genocide Studies 8, no. 3 (1994): 315-34.

19. "A Kind of Survivor," 153.

20. Ibid.

21. Sigmund Freud, Civilization and Its Discontents, ed. James Strachey (London and New York: Norton, 1961).

22. "A Season in Hell."

23. George Steiner, "The Long Life of Metaphor: An Approach to the 'Shoah,", in Writing and the Holocaust, ed. Berel Lang (New York: Holmes \& Meier, 1988), 154-71, 164.

24. Ibid.

25. Ibid., 161; see also 170 . 